\title{
COVID-19: The Promise and Failure of Law in an Inequitable Nation
}

Wendy E. Parmet, JD, Scott Burris, JD, Lance Gable, JD, MPH, Sarah de Guia, JD, Donna E. Levin, JD, and Nicolas P. Terry, LLM

\section{ABOUT THE AUTHORS}

Wendy E. Parmet is with the Center for Health Policy \& Law, Northeastern University, Boston, MA. Scott Burris is with the Center for Public Health Law Research, Temple University, Philadelphia, PA. Lance Gable is with Wayne State University Law School, Detroit, MI. Sarah de Guia is with ChangeLab Solutions, Oakland, CA. Donna E. Levin is with the Network for Public Health Law, Edina, MN. Nicolas P. Terry is with the Hall Center for Law and Health, Robert H. McKinney School of Law, Indiana University, Indianapolis.

D espite years of legal preparedness efforts-including new and reformed federal and state laws and regulationsand detailed plans to guide the response to a public health emergency, the US response to COVID-19 has been an appalling failure. As of October 2020, the United States has had more than 219000 confirmed COVID19 deaths and a death rate per 100000 far higher than that of most developed countries. ${ }^{1}$ Worse, COVID-19 deaths and infection rates exhibit stark racial, ethnic, and socioeconomic disparities. ${ }^{2}$

For the most part, law has done what it needs to do in the face of a pandemic: it has created and apportioned government powers and duties, set out rules of conduct, offered protection of individual rights against unreasonable interference, and provided tools for enforcement. Law has worked-on paper. In practice, several factors have made the implementation of the law a significant part of our failed response.

\section{A FAILURE OF LEADERSHIP}

One factor is the lack of leadership. ${ }^{3}$ Laws that empower government officials to take actions in response to a pandemic can be effective only if those powers are used and used wisely. In the current pandemic, many political leaders at both the federal and state levels have failed to use the relevant legal powers at their disposal. For example, the federal government has yet to effectively use the Defense Production Act to monitor, coordinate, and increase the production, procurement, and distribution of personal protective equipment and other needed supplies. ${ }^{3}$ Likewise, the Department of Health and Human Services has failed to use all of the flexibility granted to it by the Medicaid Act to enhance coverage during the pandemic. And despite provisions in the rapidly passed Families First Coronavirus Response Act and the Coronavirus Aid, Relief, and Economic Security Act, Congress and the President have failed in their basic federal duty to extend support for state and local governments and support Americans who have been hard hit by the recession.

The failure to use laws effectively has not been only at the federal level. In the spring of 2020, many governors chose to discontinue using their emergency powers and "reopened" their states, even when doing so clashed with the White House's own guidelines and even as most courts upheld their emergency orders. Many states have also continued to reject the expansion of their Medicaid programs. Too many states also failed to protect citizens from eviction or workers from infection-prone working conditions. Preemption also proved repeatedly problematic as governors perversely used their authority to prevent city and county officials from imposing measures responsive to local conditions. Fights over masks, school openings, and gathering bans continue to expose state-local fault lines.

\section{ENABLING LAWS TO WORK}

Even when laws are used, their efficacy may depend on a range of other factors. For example, public health agencies, including the Centers for Disease Control and Prevention (CDC), are given both legal mandates and regulatory authority. But they cannot fulfill either if they lack the resources needed to do their jobs. It is no coincidence that the nation's poor response to COVID-19 came after years of decline in federal and state funding for public health agencies. ${ }^{4}$

Political interference with the sciencebased activities of health agencies poses another problem that has loomed large during the current pandemic. When public health agencies base their actions and messaging on politics rather than science, they lose the public's confidence, and their initiatives are doomed to failure. For that reason, Congress should consider creating new legal protections for the CDC and the 
US Food and Drug Administration, potentially by reestablishing them as independent agencies. ${ }^{3}$ Likewise, governors and local officials should clearly state the scientific evidence on which their emergency orders rely. ${ }^{3}$

Individuals also need the resources and wherewithal to comply with public health laws. It is easy to issue a stay-athome order. It is considerably harder to enable people to sustain themselves and their families during a stay-at-home order or to ensure that small businesses survive shutdowns. For this reason, many of the most crucial laws during this or any pandemic are not those that empower officials but those that support individuals and small businesses, especially those in vulnerable communities. Sick leave, expanded access to health insurance, access to broadband Internet, and protections against evictions and utility shutoffs are only some of the critical measures that need to be implemented if our public health laws are to succeed and the US response is to be even remotely equitable. $^{3}$

More broadly, the United States needs to reconsider the law's role in a pandemic response. For too long, the United States has treated public health laws as cheap substitutes for public health infrastructure, as if empowering a health agency was the same as providing it with the people, expertise, information systems, and resources it needs to use its powers effectively. For decades, pandemic preparation focused too much on writing new plans and laws, ignoring the devastating effects of budget cuts and political interference with public health agencies. ${ }^{3}$ In sector after sector, potentially useful laws that were on the books were left unused, public health agencies lacked the resources to carry out their legal mandates, leaders failed to convey accurate messages, and individuals failed to receive the social supports they needed to comply with the laws that were issued.

\section{LAW'S CULPABILITY IN SOCIAL INEQUALITY}

As we assess law's role in the current pandemic, it is important to recognize not only law's unrealized potential to protect public health but also its culpability in magnifying the inequities and disparities on which COVID-19 has feasted.

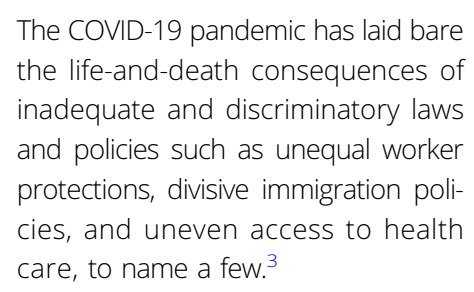
the life-and-death consequences of inadequate and discriminatory laws and policies such as unequal worker protections, divisive immigration policies, and uneven access to health care, to name a few. ${ }^{3}$

Inadequate civil rights laws, discriminatory policing practices, insufficient nursing home regulation, excessive incarceration, the federal government's failure to meet its obligations to Tribal governments, and the shortcomings of our environmental protection laws exemplify laws' contribution to the inequitable social conditions that allowed COVID-19 to reap its deadly toll on communities of color, people with disabilities, immigrants, those living in congregate spaces, and Native Americans. As we contemplate law's role in protecting the public from the next pandemic, it is critical that we look not only to reforming and bolstering public health laws but to reexamining and revising the wide array of other laws that have left this country so inequitable and thus so vulnerable to a novel coronavirus.

\section{A MORE EFFECTIVE LEGAL RESPONSE}

Legal action at the federal, state, and local levels can still be part of a better, more effective and equitable response to COVID-19 and future pandemics. In addition to the recommendations already offered, Congress and the President can use federal powers to send more money to states, cities, and struggling families; issue and enforce stronger occupational safety and health protections; use the Defense Production Act to ease medical equipment shortages; repeal the public charge rule and stop immigration enforcement that interferes with COVID-19 control; and reverse the decision to leave the World Health Organization. States that have not expanded their Medicaid program should do so. States should also limit preempting local public health measures and depopulate their prisons. Local governments can use their powers to issue control orders tailored to local epidemic conditions and to fill gaps in protection for workers and families. All leaders at every level must recognize the importance of projecting unity and clear, credible, science-based messages.

Perhaps most important, policymakers need to understand both the importance and limits of law's relationship to public health. Law is a powerful tool that can play an important role in helping a society respond to a pandemic. But for law to be effective, there must be strong leadership, ample resources fairly distributed, and the public's trust. To date, all three have been lacking. $\boldsymbol{A} \mathrm{JPH}$

\section{CORRESPONDENCE}

Correspondence should be sent to Wendy E. Parmet, 416 Huntington Ave, Boston, MA 02115 (e-mail: w.parmet@northeastern.edu). Reprints can 
be ordered at http://www.ajph.org by clicking the "Reprints" link.

\section{PUBLICATION INFORMATION}

Full Citation: Parmet WE, Burris S, Gable L, de Guia S, Levin DE, Terry NP. COVID-19: The Promise and Failure of Law in an Inequitable Nation. Am J Public Health. 2021;111(1):47-49.

Acceptance Date: October 10, 2020.

DOI: https://doi.org/10.2105/AJPH.2020.306008

\section{CONTRIBUTORS}

All authors contributed equally to this editorial.

\section{ACKNOWLEDGMENTS}

The authors wish to thank the de Beaumont Foundation, the American Public Health Association, and the Robert Wood Johnson Foundation for supporting the report Assessing Legal Responses to COVID-19, as well as all of the authors who contributed to the report and Faith Khalik, Bethany Saxon, Leslie Zellers, and Liz Voyles for their invaluable work on it.

\section{CONFLICTS OF INTEREST}

\section{REFERENCES}

1. Johns Hopkins University School of Medicine. Mortality analyses. Available at: https://coronavirus. jhu.edu/data/mortality. Accessed October 18, 2020.

2. Krieger N. ENOUGH: COVID-19, structural racism, police brutality, plutocracy, climate change-and time for health justice, democratic governance, and an equitable sustainable future. Am J Public Health. 2020;110(11):1620-1623. https://doi.org/10.2105/ AJPH.2020.305886

3. Burris $S$, de Guia $S$, Gable L, Levin DE, Parmet WE, Terry NP, eds., Assessing legal responses to COVID-19. Available at: https://static1.squarespace. com/static/5956e16e6b8f5b8c45f1c216/t/ 5f36c0702e9042616f13505c/1597423914220/ COVID19PolicyPlaybook_Aug2020.pdf. Accessed October 18, 2020

4. Trust for America's Health. The impact of chronic underfunding of America's public health system: trends, risks, and recommendations, 2019. Available at: https://www.tfah.org/report-details/2019funding-report. Accessed October 18, 2020 